\title{
SUATU TINJAUAN TENTANG TENAGA KERJA BURUH DI INDONESIA
}

\author{
Idi SetyoUtomo ${ }^{1}$
}

\begin{abstract}
Article discusses problems faced by the labor in Indonesia. To make a good relationship between companys' owner and labor, there will be an active and positive role of bipartit department in the company. In order to make an indutrial relationship is in harmony in the future, it is suggested that every problem in the company should be solved by the bipartit department with "win-win solution".
\end{abstract}

Keywords: work force, labor

\section{ABSTRAK}

Artikel membahas permasalahan yang dihadapi oleh para pekerja/buruh di Indonesia. Untuk menjalin adanya hubungan yang harmonis antara unsur pengusaha dan unsur pekerja/buruh, diharapkan peranan aktif dan positif dari lembaga kerja sama bipartit yang berada di perusahaan. Agar perjalanan ke depan bagi terjalinnya hubungan industrial yang harmonis ini dapat terwujud secara berkelanjutan, disarankan setiap pemasalahan yang muncul di perusahaan dapat diselesaikan oleh lembaga bipartit dengan pemahaman yang sama terhadap bagaimana memecahkan masalah didasarkan pada "win-win solution".

Kata kunci: tenaga kerja, buruh

\footnotetext{
${ }^{1}$ Staf pengajar Fakultas Ekonomi, UBiNus, Jakarta
} 


\section{PENDAHULUAN}

Beberapa bulan di sepanjang tahun 2004 ini, hampir setiap hari kita membaca dan menyaksikan pemberitaan di media massa, baik cetak maupun elektronik, mengenai ratusan bahkan ribuan tenaga kerja (buruh) yang berunjuk rasa di sejumlah instansi, antara lain di depan istana negara, di gedung Dewan Perwakilan Rakyat, sampai di Departemen Tenaga Kerja dan Transmigrasi jalan Gatot Subroto, Jakarta. Apa yang mereka inginkan sehingga rela mengorbankan waktu, tenaga, dan bahkan biaya yang tidak sedikit dalam kegiatan ini, pada umumnya berkisar masalah hak normatif dan masalah pemutusan hubungan kerja (PHK). Berita mengenai buruh yang berunjuk rasa karena menuntut permasalahan mereka diselesaikan secara adil adalah sah-sah saja sepanjang dilakukan menurut peraturan perundangan yang berlaku. Tuntutan mengenai hak normatif yang mereka ajukan, misalnya di kota Tangerang diberitakan bahwa karyawan PT Cosmos di bayar di bawah upah minimum (Kompas, 23 Oktober 2001). Di Semarang, ribuan buruh turun ke jalan menuntut Upah Minimum Regional (UMR) tahun 2002 yang hanya sebesar Rp350.000,00 per bulan (Kompas, 3 Oktober 2002).

Tuntutan rekan buruh mengenai PHK, misalnya 527 buruh pabrik di bagian pemintalan Gabungan Koperasi Batik Indonesia (GKBI) yang pabriknya terbakar pada 7 Desember 2002 berunjuk rasa karena tidak menerima PHK yang dilakukan pihak perusahaan yang menurut mereka tidak memenuhi syarat (Sinar Harapan, 3 Januari 2003). Apalagi PHK yang melibatkan ratusan buruh tersebut hanya disetujui oleh Kepala Sub Dinas Tenaga Kerja Kabupaten Sleman yang bukan menjadi wewenangnya. Bahkan, peristiwa yang sangat menyedihkan pun terjadi saat penulis menyaksikan sendiri ketika sejumlah karyawan PT Dirgantara Indonesia melakukan demo ke kantor Departemen Tenaga Kerja dan Transmigrasi di jalan Gatot Subroto, Jakarta pada Selasa 21 September 2004 sekitar pukul 13.30 WIB. Mereka melakukan demo setelah gugatan mereka atas putusan Panitia Penyelesaian Perselisihan Perburuhan Pusat (P4P) mengenai PHK terhadap karyawan PT Dirgantara Indonesia ditolak oleh Pengadilan Tinggi Tata Usaha Negara di Jakarta beberapa jam sebelumnya pada hari yang sama.

Banyaknya pemberitaan di media massa maupun munculnya aksi demo mengenai masalah tenaga kerja atau perburuhan tersebut menunjukkan bahwa masalah ketenagakerjaan atau perburuhan adalah suatu kenyataan yang telah menjadi bagian dari kehidupan bangsa Indonesia. Terlebih ketika krisis multidimensi ini belum dapat diatasi secara tuntas maka masalah ketenagakerjaan/perburuhan akan selalu muncul setiap saat dan hal tersebut memerlukan penanganan yang penuh arif bijaksana. Rekan pekerja atau buruh tersebut, baik secara langsung maupun tidak langsung, telah ikut ambil bagian terhadap keberhasilan kinerja perusahaan mereka dalam meraih laba pada masa sebelum munculnya permasalahan. Pada masa resesi ini, kemampuan atau daya beli masyarakat memang mengalami penurunan sehingga banyak perusahaan yang mengalami kesulitan keuangan yang berakibat pada penurunan pendapatan yang pada akhirnya mengarah kepada kerugian perusahaan dan bagi perusahaan yang mengalami hal tersebut dapat 
melakukan PHK terhadap pekerja/buruh. Menurut undang-undang, perusahaan memang dapat melakukan PHK terhadap pekerja/buruh karena perusahaan tutup yang disebabkan perusahaan mengalami kerugian secara terus menerus selama dua tahun atau keadaan memaksa (force majeur). Selanjutnya, menurut ketentuan pasal 164 ayat 2 UndangUndang No. 13 Tahun 2003, perusahaan yang menderita kerugian diwajibkan membuktikan dengan laporan keuangan secara dua tahun terakhir yang diaudit oleh akuntan publik.

\section{PEMBAHASAN}

\section{Gambaran Umum Perburuhan}

Sebenarnya kita sudah sering mendengar kata buruh ini sejak lama. Di seluruh dunia bahkan di Indonesia, setiap awal Mei pada setiap tahun adalah merupakan bulan yang ada kaitannya dengan buruh. Hal itu dapat dipahami sebagaimana diberitakan oleh Kompas edisi 1 Mei 2003 sebagai berikut: "Ribuan buruh berunjuk rasa di Jakarta dan berbagai daerah di Indonesia memperingati Hari Buruh Sedunia (Mayday)”. Tidak diketahui secara pasti dari mana kata buruh itu berawal. Akan tetapi, menurut seorang sosiolog yang mengupas mengenai Konflik Sosial, dikatakan bahwa kata buruh berasal dari bahasa lisan petani Jawa yang kemudian diidentifikasikan dengan konsep proletariat yang menunjukkan pada suatu hubungan konfliktual antara pekerja dan majikan dengan penekanan pada ide perjuangan kelas (Susetiawan, 2000).

Buruh, menurut Undang-Undang No. 22 Tahun 1957 tentang Penyelesaian Perselisihan Perburuhan, pasal 1 ayat a ditulis sebagai berikut: "Buruh ialah barang siapa bekerja pada majikan dengan menerima upah”. Menurut Undang-Undang No. 13 Tahun 2003 tentang Ketenagakerjaan, buruh disamakan dengan pekerja. Hal itu dapat dibaca seperti tertulis pada pasal 1 ayat 3 yang berbunyi: "Pekerja/buruh adalah setiap orang yang bekerja dengan menerima upah atau imbalan dalam bentuk lain”. Istilah buruh di dalam Kamus Besar Bahasa Indonesia (KBBI) adalah orang yang bekerja untuk orang lain dengan mendapat upah atau sama dengan pekerja. Mengenai buruh itu di dalam KBBI lebih lanjut dibedakan adanya tiga klasifikasi buruh, yaitu pertama buruh kasar yang berarti buruh yang menggunakan tenaga fisiknya karena tidak mempunyai keahlian di bidang tertentu. Kedua buruh terampil, yaitu buruh yang mempunyai keterampilan di bidang tertentu, dan ketiga buruh terlatih, yaitu buruh yang sudah dilatih untuk keterampilan tertentu. Kata pekerja sendiri dalam KBBI tersebut memiliki dua pengertian. Pengertian pertama adalah orang yang bekerja dan yang kedua orang yang menerima upah atas hasil kerjanya; buruh; karyawan.

Berangkat dari definisi mengenai buruh tersebut maka setiap orang yang bekerja kepada orang lain dan mendapat upah juga termasuk kelompok pekerja atau buruh. Namun, dalam kenyataan kehidupan sehari-hari, kata buruh sering diidentikkan dengan 
mereka yang bekerja di bagian lapangan dalam suatu industri pertanian, industri perkebunan, suatu perusahaan manufaktur, atau pabrik dengan klasifikasi yang pertama dalam KBBI, yaitu buruh kasar. Hal itu mengakibatkan buruh sering diberi penekanan "rendah" dibanding pekerja. Banyak orang yang tidak bersedia atau tidak mau mengidentifikasikan dirinya sebagai buruh, meskipun dalam beberapa definisi tersebut mereka termasuk dalam kategori buruh. Mereka lebih senang menyebut diri mereka sebagai pekerja atau karyawan/karyawati. Bagi orang-orang tertentu, istilah buruh identik dengan orang rendahan, orang miskin, lemah tidak berdaya, tidak berpendidikan, kasar, kotor, dan berbagai sebutan lain yang amat merendahkan. Kondisi buruh seperti itulah sehingga di beberapa perusahaan, kelompok itu sempat mengalami pengalaman yang sangat menyedihkan. Misalnya, kaum wanita sering mengalami pelecehan seksual, bahkan ada yang "dieksploitasi" sehingga berakibat munculnya demo, seperti dikemukakan dalam awal tulisan ini. Hal itu berbeda dengan istilah karyawan/karyawati yang dirasakan lebih halus maknanya.

Sebenarnya, jika menghayati definisi yang dikemukakan oleh Undang-Undang No.13 Tahun 2003, dalam hal ini Pemerintah dan Dewan Perwakilan Rakyat sudah mencoba untuk mengangkat citra positif dari kata buruh ini dengan menyebutkan: "Pekerja/buruh adalah setiap orang yang bekerja dengan menerima upah atau imbalan dalam bentuk lain”. Artinya, buruh itu juga dianggap sebagai pekerja, suatu definisi yang diambil maknanya dari KBBI. Oleh karena itu, akibat dari adanya pembedaan makna itu, maka mereka yang sama-sama menerima upah atau digaji atau menerima imbalan dalam bentuk lain merasa bukan berada dalam golongan yang sama (buruh), hanya karena tempat atau lokasi pekerjaan mereka berbeda. Terlebih bagi mereka yang bekerja di dalam ruangan kantor yang sejuk dan nyaman menggunakan jas dan berdasi serta digaji tinggi dan memperoleh berbagai fasilitas yang "wah”, akan menganggap diri mereka bukan buruh, tetapi karyawan/karyawati.

\section{Buruh dari Waktu ke Waktu}

Pada zaman penjajahan (kolonial), khususnya yang dilakukan oleh Belanda, keberadaan golongan orang dengan sebutan buruh tidak begitu menonjol. Pada masa itu, adanya sistem feodalisme mengakibatkan munculnya perbedaan kelas yang pada akhirnya terdapat golongan orang kelas bawah, seperti budak atau kuli yang bekerja pada orangorang yang memiliki kelas lebih tinggi atau para bangsawan. Berdasarkan fakta sejarah, pada waktu sebelum masa penjajahan datang dan selama masa penjajahan itu sendiri, di Indonesia telah terdapat berbagai macam kerajaan yang tersebar di wilayah nusantara. Tiap daerah kerajaan memiliki sejarahnya sendiri-sendiri dan sudah barang tentu juga memiliki sistem politik dan susunan masyarakat yang berbeda. Namun, di antara perbedaan tersebut ternyata ada suatu ciri khusus yang tidak jauh berbeda di antara kerajaan satu dan kerajaan lainnya. Ciri khusus tersebut adalah adanya kharisma dan otoritas raja terhadap rakyatnya, serta rakyat yang mengabdi kepada raja dan raja yang memberikan perlindungan kepada rakyatnya. Para raja atau bangsawan tersebut pada umumnya memiliki dominasi terhadap tanah dalam jumlah yang cukup luas. 
Pada saat itu, tanah dikuasai secara timpang dan tanah menjadi basis bagi penguasaan politik. Sebagai akibatnya, dari penguasaan tanah yang merupakan sumber daya produksi tersebut, bagi mereka yang tidak memiliki tanah akan mengalami tekanan dan eksploitasi yang merendahkan martabat kemanusiaannya melalui pekerjaan sebagai penggarap tanah atau menjadi budak dari tuan tanah. Dari sinilah kelas buruh tani itu muncul karena mereka harus bekerja untuk mendapatkan upah dari tuan mereka demi mempertahankan kehidupan mereka dan keluarganya. Dengan bekerja pada orang lain, berarti buruh itu memberikan dirinya diperbudak oleh orang lain atau orang yang memiliki sumber daya. Mengenai kondisi buruh itu, Jan Breman mengemukakan bahwa akibatnya mereka sering kali dipandang rendah, tidak berharkat dibanding orang merdeka. Meskipun mereka mengambil bagian dalam proses produksi dalam suatu industri, namun tetap saja cara mereka dipekerjakan tak ubah layaknya orang yang tidak memiliki harga diri (Breman, 1977).

Dalam perjalanan sejarah, setelah bangsa Indonesia memperoleh kemerdekaan di tahun 1945 sampai pada masa orde lama, kondisi dunia kerja (kaum buruh) tidak menunjukkan ke arah yang lebih baik dibanding pada masa sebelum kemerdekaan (kolonial). Buruh yang bekerja di sektor pertanian, sektor manufaktur skala kecil, dan menengah, seperti industri rokok dan tekstil memiliki standar upah yang sangat kecil disertai kondisi kerja yang sangat buruk. Demikian juga di era orde baru dan di zaman reformasi sekali pun, kondisi buruh itu sangat memprihatinkan, yaitu standar upah yang jauh memenuhi kebutuhan (sangat minim), kondisi kerja yang buruk, serta jaminan keamanan kerja yang tidak menentu. Dalam hal ini berarti hak normatif buruh atau pekerja yang mestinya mereka terima secara wajar sebagai hak dasar mereka, masih banyak yang diabaikan oleh para pengusaha. Tidak mengherankan apabila banyak tuntutan yang diajukan oleh para buruh ini agar para pengusaha memenuhi hak mendasar mereka dalam bentuk demo, seperti disajikan di awal artikel ini.

Sebagai gambaran mengenai minimnya penghasilan bagi buruh itu, Kompas edisi Kamis, 4 Nopember 2004 pada halaman 13 menulis dengan judul sangat besar: "Disesalkan, UMP DKI di bawah KHM". Kalau kita baca isi berita tersebut yang dimaksud dengan UMP adalah Upah Minimum Provinsi dan DKI adalah kepanjangan dari Daerah Khusus Ibukota. KHM adalah kepanjangan dari Kebutuhan Hidup Minimum. Dengan demikian, isi judul berita tersebut adalah bahwa penetapan Pemerintah Propinsi DKI Jakarta mengenai UMP tahun 2005 sebesar Rp711.000,00 per bulan bagi tenaga kerja/buruh di Propinsi DKI Jakarta, masih jauh berbeda dengan KHM yang besarnya Rp873.945,00 per bulan. Walaupun penetapan UMP DKI Jakarta tahun 2005 tersebut sudah lebih tinggi dibanding UMP DKI Jakarta tahun sebelumnya yang hanya sebesar Rp671.550,45 per bulan, tetap saja banyak pihak yang mengutarakan penyesalannya. Pihak yang menyesalkan penetapan UMP DKI Jakarta tahun 2005 tersebut, antara lain Maringan Pangaribuan, Wakil Ketua DPRD DKI Jakarta (Fraksi Partai Demokrasi Indonesia Perjuangan) dan Ilal Ferhard (Fraksi Partai Demokrat). Sebagaimana diatur oleh undang-undang maka pada setiap akhir tahun, masing-masing Kepala Daerah Propinsi di seluruh Indonesia menetapkan upah minimum propinsi bagi tenaga 
kerja/buruh yang berlaku di wilayah propinsi yang bersangkutan. Berdasarkan pengalaman selama ini, penetapan UMP di setiap propinsi selalu mendapat tentangan, terutama dari para pekerja/buruh. Dalam hal ini, pihak pekerja/buruh selalu berada pada sisi yang lemah karena kenyataannya UMP yang mereka terima masih jauh berada di bawah KHM dan dalam praktiknya banyak pengusaha yang membayarkan upah pekerja/buruh mereka di bawah UMP dengan alasan perusahaan tidak mampu membayar sesuai UMP.

Sebenarnya, untuk melindungi nasib buruh atau pekerja ini, pemerintah bersama Dewan Perwakilan Rakyat telah membuat perangkat berupa undang-undang yang telah ditindaklanjuti dengan berbagai peraturan pelaksanaannya, seperti keputusan menteri yang membawahi bidang ketenagakerjaan. Peraturan perundangan tersebut, misalnya Undang-Undang No. 22 Tahun 1957 tentang Penyelesaian Perselisihan Perburuhan, Undang-Undang No. 12 Tahun 1964 tentang Pemutusan Hubungan Kerja di Perusahaan Swasta; dan Keputusan Menteri Tenaga Kerja No. 150/Men/2000 tentang Penyelesaian Pemutusan Hubungan Kerja dan Penetapan Uang Pesangon, Uang Penghargaan Masa Kerja, dan Ganti Kerugian, dan masih banyak peraturan lagi. Bahkan, peraturan perundangan terakhir yang dikeluarkan Pemerintah bersama Dewan Perwakilan Rakyat adalah dibuatnya Undang-Undang No. 13 Tahun 2003 tentang Ketenagakerjaan dan Undang-undang No. 2 Tahun 2004 tentang Penyelesaian Perselisihan Hubungan Industrial. Hanya masalahnya, menurut kacamata buruh/pekerja, berbagai peraturan tersebut masih belum berpihak kepada buruh atau pekerja. Seperti, Undang-Undang No. 13 Tahun 2003, kelahirannya yang banyak mendapat tentangan dari kaum buruh/pekerja dan sejumlah Lembaga Swadaya Masyarakat sampai saat ini pun masih dianggap belum berpihak kepada tenaga kerja/buruh.

\section{Panitia Penyelesaian Perselisihan Perburuhan Pusat (P4P)}

Walaupun perangkat di bidang ketenagakerjaan sudah cukup banyak, bukan berarti bahwa perselisihan antara buruh dan majikan atau pengusaha tidak akan timbul. Perselisihan perburuhan ialah pertentangan antara majikan atau perkumpulan majikan dengan serikat buruh atau gabungan serikat buruh berhubung dengan tidak adanya persesuaian paham mengenai hubungan kerja, syarat kerja dan/atau keadaan perburuhan (Undang-Undang No. 22 Tahun 1957). Apabila muncul perselisihan perburuhan maka pekerja/buruh atau serikat pekerja/serikat buruh dan majikan diharapkan mencari penyelesaian secara damai dengan jalan perundingan.

Dalam hal ini, diupayakan agar penyelesaian masalah tersebut dilakukan secara perundingan melalui lembaga kerja sama bipartit, yaitu suatu lembaga yang berfungsi sebagai forum komunikasi dan konsultasi mengenai hal ketenagakerjaan di perusahaan. Lembaga bipartit itu susunan keanggotaanya terdiri atas unsur pengusaha dan unsur pekerja/buruh yang ditunjuk oleh pekerja/buruh secara demokratis untuk mewakili kepentingan pekerja/buruh di perusahaan yang bersangkutan. Proses penyelesaian perselisihan perburuhan ini dapat berlangsung cepat atau sebaliknya bahkan dapat 
memakan waktu lama, apabila masing-masing pihak tidak dapat menerima kesepakatan. Jika perundingan yang dimaksudkan tidak mencapai kesepakatan maka masalah tersebut akan diajukan kepada pegawai perantara dari Dinas Tenaga Kerja tingkat Kabupaten atau Kota yang berada di lokasi perusahaan tersebut melakukan usaha. Dalam perundingan tersebut, pegawai perantara akan mengeluarkan anjuran kepada para pihak yang berselisih. Apabila salah satu pihak menolak anjuran pegawai perantara maka masalah tersebut akan diajukan ke Panitia Penyelesaian Perselisihan Perburuhan Daerah (P4D) untuk disidangkan dan diputuskan. P4D itu dibentuk oleh menteri yang membidangi ketenagakerjaan yang berkedudukan di ibukota propinsi di seluruh Indonesia. Menurut ketentuan, keanggotaan P4D itu terdiri atas seorang wakil kementerian perburuhan sebagai ketua merangkap anggota dan anggota lainnya terdiri atas seorang wakil kementerian perindustrian, seorang wakil kementerian keuangan, seorang wakil kementerian pertanian, serta seorang wakil kementerian perhubungan atau kementerian pelayaran, 5 orang dari kalangan majikan dan 5 orang wakil dari serikat pekerja/serikat buruh. Untuk tiap anggota, ditunjuk seorang anggota pengganti.

Apabila dalam penyelesaian di P4D ada salah satu pihak yang merasa keberatan atas keputusan yang dikeluarkan oleh P4D maka kepada pihak yang bersangkutan diberikan kesempatan untuk mengajukan banding kepada Panitia Penyelesaian Perselisihan Perburuhan Pusat (P4P). P4P itu dibentuk berdasarkan Keputusan Presiden RI dan keanggotaannya terdiri atas seorang wakil kementerian perburuhan sebagai ketua merangkap anggota, dan seorang wakil kementerian perindustrian, seorang wakil kementerian keuangan, seorang wakil kementerian pertanian, seorang wakil kementerian perhubungan atau kementerian palayaran, 5 (lima) orang dari kalangan pekerja/buruh dan 5 (lima) orang dari kalangan majikan. Seperti halnya keanggotan P4D, maka tiap anggota P4P ditunjuk seorang anggota pengganti. Berdasarkan Undang-Undang No.22 Tahun 1957, P4P itu berkedudukan di Jakarta. Kasus yang berkaitan dengan tenaga kerja atau buruh yang disampaikan dan diproses di P4P itu mengenai dua hal, yaitu yang pertama masalah Perselisihan Hubungan Industrial (PHI) (yang menyangkut hak normatif) dan yang kedua adalah masalah Pemutusan Hubungan Kerja (PHK). Berikut ini disajikan perkembangan penyelesaian perkara PHI dan PHK oleh P4P pada periode 1998 sampai dengan 29 Februari 2004, seperti pada Tabel 1.

Tabel 1 Perkembangan Penyelesaian Perkara PHI dan PHK oleh P4 Pusat Periode 1998 sampai dengan 29 Februari 2004

\begin{tabular}{|c|c|c|c|c|c|c|c|c|c|}
\hline \multirow{2}{*}{ No } & \multirow{2}{*}{ Tahun } & \multicolumn{2}{|c|}{ Perkara yang Masuk } & \multicolumn{3}{|c|}{ Perkara yang Diputus } & \multicolumn{2}{|c|}{$\begin{array}{l}\text { Digugat ke } \\
\text { Pengadilan Tinggi } \\
\text { TUN oleh: }\end{array}$} & \multirow{2}{*}{$\begin{array}{c}\text { Persenta: } \\
\text { (\%) } \\
\text { Gugatar }\end{array}$} \\
\hline & & PHI & PHK & PHI & PHK & TK & $\begin{array}{r}\text { TU } \\
\text { Pekerja }\end{array}$ & $\begin{array}{l}\text { N oleh: } \\
\text { Pengusaha }\end{array}$ & \\
\hline 1 & 2 & 3 & 4 & 5 & 6 & 7 & 8 & 9 & 10 \\
\hline 1 & 1998 & 25 & 2.172 & 22 & 2.0341 & 128.059 & 27 & 93 & 5,83 \\
\hline 2 & 1999 & 65 & 2.386 & 59 & $2.207 \quad 1$ & 107.815 & 48 & 144 & 8,47 \\
\hline 3 & 2000 & 82 & 2.124 & 79 & 2.015 & 75.088 & 61 & 173 & 11,17 \\
\hline
\end{tabular}


Tabel 1 Perkembangan Penyelesaian Perkara PHI dan PHK oleh P4 Pusat Periode 1998 sampai dengan 29 Februari 2004 (lanjutan)

\begin{tabular}{rrrrrrrrrr}
\hline 4 & 2001 & 98 & 2.312 & 84 & 1.994 & 79.984 & 68 & 199 & 12,85 \\
5 & 2002 & 115 & 2.663 & 91 & 2.080 & 98.575 & 81 & 212 & 13,50 \\
6 & 2003 & 130 & 2.977 & 110 & 2.460 & 128.739 & 79 & 159 & 9,26 \\
7 & 2004 & 32 & 925 & 14 & 233 & 18.928 & 10 & 51 & 24,69 \\
\hline
\end{tabular}

Sumber: Panitia Penyelesaian Perselisihan Perburuhan Pusat (P4P).

Keterangan:

P4 Pusat $=$ Panitia Penyelesaian Perselisihan Perburuhan Pusat

PHI = Penyelesaian Hubungan Industrial

PHK = Pemutusan Hubungan Kerja

TUN = Tata Usaha Negara

TK = Tenaga Kerja yang mengalami PHK

Dari tabel tersebut dapat dibaca bahwa kasus PHI yang masuk ke P4P ada kecenderungan selalu meningkat dari tahun ke tahun, yaitu masing-masing tahun 1998: 25 kasus, tahun 1999: 65 kasus, tahun 2000: 82 kasus, tahun 2001: 98 kasus, tahun 2002: 115 kasus, dan tahun 2003: 130 kasus. Paling banyak terjadi adalah pada tahun 2003 dengan 130 kasus dan yang telah diputus oleh P4P sebanyak 110 kasus. Data perkembangan penyelesaian perkara PHI pada tahun 2004 yang berhasil dihimpun baru sampai bulan Februari dengan kasus PHI sebanyak 32 kasus dan yang telah diputus P4P sebanyak 14 kasus.

Mengenai masalah PHK juga sangat memprihatinkan karena dari tahun 1998, kasusnya yang masuk ke P4P kecenderungannya selalu meningkat, yaitu tahun 1988 sebanyak 2.172 kasus, tahun 1999 sebanyak 2.386 kasus, tahun 2000 sebanyak 2.124 kasus, tahun 2001 sebanyak 2.312 kasus, tahun 2002 sebanyak 2.663 kasus dan tahun 2003 sebanyak 2.977 kasus. Pada tahun 2003 dari kasus PHK yang masuk ke P4P sebanyak 2.977 kasus, dan telah diputuskan oleh P4P sebanyak 2.460 kasus dengan pihak tenaga kerja/buruh yang mengalami PHK sebanyak 128.739 pekerja/buruh. Pada tahun 2004 sampai dengan bulan Februari masalah PHK yang masuk ke P4P sebanyak 925 kasus, dan yang telah diputus sebanyak 233 kasus dengan tenaga kerja yang mengalami PHK sebanyak 18.928 pekerja/buruh.

Selain menyidangkan kasus gugatan dari para pihak yang menolak keputusan P4D, P4P juga menyidangkan kasus PHK massal atau yang melibatkan tenaga kerja/buruh dengan jumlah lebih dari 10 (sepuluh) orang. Dari kasus PHI dan PHK yang ditangani oleh P4P tersebut, baik pihak pekerja/buruh maupun pihak pengusaha, selalu ada yang tidak puas dengan keputusan P4P sehingga mereka akan mengajukan gugatan ke Pengadilan Tinggi Tata Usaha Negara. Dari data tersebut, persentase gugatan yang diajukan terhadap keputusan P4P ke Pengadilan Tinggi Tata Usaha Negara pada periode 1998 sampai dengan 2004, baik oleh pihak pekerja/buruh dan pihak pengusaha, 
kecenderungannya terlihat semakin naik dari tahun ke tahun. Pada tahun 1998 gugatan tersebut sebesar 5,83\%, tahun 1999 sebesar 8,47\%, tahun 2000 sebesar 11,17\%, tahun 2001 sebesar 12,85\%, dan tahun 2002 sebesar 13,50\%. Hanya pada tahun 2003 gugatan kedua pihak sedikit menurun, yaitu hanya 9,26\%. Kalau diperhatikan masing-masing gugatan maka terlihat bahwa gugatan terhadap keputusan P4P didominasi oleh pihak pengusaha dan yang tertinggi adalah pada tahun 2002, yaitu sebanyak 212 pengusaha yang mengajukan gugatan ke Pengadilan Tinggi Tata Usaha Negara. Walaupun pada tahun 2004 gugatan kedua pihak terlihat cukup tinggi, yaitu sebesar 24,69\%, namun hal tersebut belum dapat menggambarkan kasusnya untuk sepanjang tahun 2004 karena data yang diperoleh baru sampai pada bulan Februari saja.

Mengingat banyaknya kasus, baik mengenai PHI maupun mengenai PHK tersebut, muncul adanya keinginan dari kelompok pekerja atau buruh untuk mengadakan upaya konkrit mengamandemen sebagian pasal dari Undang-Undang No. 13 Tahun 2003 yang menurut mereka sangat tidak berpihak kepada pekerja/buruh. Pada saat berdialog dengan sebagian pemimpin serikat pekerja/serikat buruh yang tergabung dalam Komite Nasional Gerakan Pekerja Buruh Indonesia (KOMNAS GPBI), Kamis 16 September 2004, Presiden Megawati Soekarnoputri menyetujui keinginan tersebut, yaitu untuk melakukan amandemen terhadap sejumlah pasal dalam Undang-Undang No. 13 Tahun 2003 tentang Ketenagakerjaan (Kompas, 17 September 2004). Amandemen Undangundang itu disetujui karena ada sejumlah pasal yang dinilai masih kurang memberikan perlindungan bagi tenaga kerja/buruh. Hal yang menarik disini adalah amandemen terhadap Undang-Undang No.13 Tahun 2003 tidak hanya diinginkan oleh para pekerja atau buruh tetapi juga diinginkan oleh para pengusaha di Indonesia. Harapan pengusaha, dengan dilakukannya amandemen terhadap Undang-Undang No.13 Tahun 2003 tersebut adalah dalam rangka upaya meningkatkan investasi dan menyerap tenaga kerja.

Hal tersebut dikemukakan oleh Djimanto, Sekretaris Jenderal Dewan Pimpinan Nasional Asosiasi Pengusaha Indonesia (APINDO). Dengan tegas Djimanto mengatakan bahwa pemerintah memang harus merevisi undang-undang ketenagakerjaan. Selanjutnya, Djimanto mengatakan jika pemerintah mengedepankan investasi untuk menyerap tenaga kerja, pasal yang harus direvisi adalah Bab XII pasal 150 sampai pasal 172 tentang pemutusan hubungan kerja, dan sejumlah pasal lainnya (Kompas, 17 September 2004).

Dalam hal ini, gayung telah bersambut, di satu pihak para pekerja atau buruh menginginkan adanya amandemen terhadap Undang-Undang No.13 Tahun 2003, di pihak lain, APINDO pun menginginkan hal serupa meskipun penekanan revisi atau amandemen terhadap pasalnya mungkin saja berbeda, sesuai kepentingan masing-masing. Sebenarnya, dalam upaya terwujudnya hubungan yang serasi antara pihak pekerja/buruh dan pengusaha serta dengan pemerintah, telah diamanatkan oleh undang-undang agar tercipta suatu hubungan yang harmonis dengan istilah hubungan industrial diantara pelaku proses produksi di Indonesia. Hubungan industrial sebagaimana dikemukakan dalam UndangUndang No.13 Tahun 2003 adalah suatu sistem hubungan yang terbentuk antara pelaku dalam proses produksi barang dan/atau jasa yang terdiri atas unsur pengusaha, 
pekerja/buruh, dan pemerintah yang didasarkan pada nilai Pancasila dan Undang-Undang Dasar Negara Republik Indonesia Tahun 1945.

\section{PENUTUP}

\section{Simpulan}

Semua pihak tentu ikut merasa prihatin dengan munculnya permasalahan yang dihadapi oleh para pekerja/buruh ini dan kita semua mengharapkan agar munculnya aksi demo oleh pekerja/buruh di masa depan dapat semakin berkurang. Berdasarkan pengalaman selama ini, kegiatan aksi demo selalu berakibat kontra produktif bagi siapa saja, baik bagi buruh itu sendiri, pengusaha, maupun bagi instansi pemerintah. Untuk menjalin adanya hubungan yang harmonis antara unsur pengusaha dan unsur pekerja/buruh, diharapkan peranan aktif dan positif dari lembaga kerja sama bipartit yang berada di perusahaan. Agar perjalanan ke depan bagi terjalinnya hubungan industrial yang harmonis ini dapat terwujud secara berkelanjutan, disarankan setiap pemasalahan yang muncul di perusahaan dapat diselesaikan oleh lembaga bipartit dengan pemahaman yang sama terhadap bagaimana memecahkan masalah didasarkan pada "win-win solution".

Untuk mencapai tahap penyelesaian masalah berdasarkan "win-win solution", anggota lembaga bipartit itu sangat memegang peran menentukan. Dalam arti, setiap ada masalah yang timbul diusahakan secara maksimal agar dapat diselesaikan antara dua pihak saja, yaitu antara unsur pengusaha dan unsur pekerja/pekerja. Berdasarkan pengalaman, apabila permasalahan yang muncul di suatu perusahaan tidak dapat diselesaikan oleh lembaga bipartit, hal itu berarti akan memerlukan proses yang panjang dan biaya cukup banyak serta sangat melelahkan karena harus diproses secara berjenjang sampai para pihak memperoleh keputusan yang final. Seperti dicontohkan sebelumnya, rekan dari PT Dirgantara Indonesia yang tidak puas terhadap keputusan PHK mereka oleh Panitia Penyelesaian Perselisihan Perburuhan Pusat dan mengajukan gugatan ke Pengadilan Tinggi Tata Usaha Negara. Karena gugatan mereka dikalahkan oleh Pengadilan Tinggi Tata Usaha Negara, upaya mereka sekarang ini adalah mengajukan kasasi ke Mahkamah Agung yang berarti akan memakan waktu lama lagi dan biaya yang bertambah besar. Keputusan yang diperoleh belum tentu memuaskan para pekerja/buruh.

Selain itu, dalam rangka menciptakan iklim usaha yang memberikan perlindungan kepada tenaga kerja/buruh dan sekaligus memenuhi keinginan pihak pengusaha guna pengembangan investasi maka upaya keinginan untuk mengamandemen beberapa pasal dari Undang-Undang No.13 Tahun 2003 tentang Ketenagakerjaan disarankan kepada pemerintah yang baru terpilih ini untuk mempertimbangkan keinginan tersebut. Adapun pasal yang perlu direvisi, antara lain masalah penggunaan sumber daya dari luar (outsourcing), pekerja waktu tertentu, mogok kerja, penetapan pesangon yang 
dikaitkan dengan hak pensiun, hak pekerja/buruh yang mengundurkan diri, dan ketentuan sanksi yang sangat lemah dan tidak adil sehingga merugikan pekerja/buruh.

Selama ini, UMP/UMR selalu menjadi masalah setiap akan ditetapkan oleh Gubernur Kepala Daerah Pemerintah Propinsi. Hal itu karena dengan sistem pengupahan yang ditetapkan berdasarkan UMP/UMR, tuntutan kenaikan UMP/UMR selalu muncul setiap tahun. Lagi pula UMP/UMR yang berlaku sekarang ini berlaku bagi seluruh sektor tanpa memedulikan kemampuan perusahaan karena ada peluang bagi pengusaha mengajukan penundaan penerapan UMP/UMR, jika perusahaan merasa belum mampu. Dalam rangka menghindari tuntutan yang selalu muncul setiap tahun, disarankan pada masa mendatang agar penetapan besaran pengupahan per bulan bagi pekerja/buruh itu perlu dipikirkan supaya dapat lebih adil, baik bagi kalangan pengusaha maupun bagi kalangan pekerja/buruh. Misalnya, penentuan besaran upah per bulan ditetapkan berpedoman pada produktivitas, performa, dan kontribusi pekerja/buruh di sektor industri masing-masing, serta perlu diperhitungkan agar besaran upah per bulan bagi pekerja/buruh di setiap propinsi harus diupayakan minimal sama atau di atas angka Kebutuhan Hidup Minimum (KHM).

\section{DAFTAR PUSTAKA}

Breman, Jan. 1977. Menjinakkan Sang Kuli: Politik Kolonial Awal Abad 20. Jakarta: Pustaka Umum Grafiti. Terj. Koesalah Soebagyo Toer, dari buku: Koelies, Planters en Koloniale Politiek: Het Arbeidsregime op de Grootlandbouwondernemingen aan Sumatra's Oostkust in Het Begin Van De Twintigeste Eeuw.

Pusat Bahasa, Departemen Pendidikan Nasional. 2001. Kamus Besar Bahasa Indonesia. Edisi Ketiga, Cet. 1. Jakarta: Balai Pustaka.

Susetiawan. 2000. Konflik Sosial: Kajian Sosiologis Hubungan Buruh, Perusahaan dan Negara di Indonesia. Cet.ke-1. Yogyakarta: Pustaka Pelajar.

Undang-Undang No. 22 Tahun 1957. Tentang Penyelesaian Perselisihan Perburuhan.

Undang-Undang No. 12 Tahun 1964. Tentang Pemutusan Hubungan Kerja di Perusahaan Swasta.

Undang-Undang No. 13 Tahun 2003. Tentang Ketenagakerjaan.

Undang-Undang No. 2 Tahun 2004. Tentang Penyelesaian Perselisihan Hubungan Industrial. 